\title{
Ettevõtluspädevust toetavate programmide mõju õpilaste võimekuse ja loovusega seotud uskumuste ning sotsiaalsete oskuste kujunemisele
}

\author{
Grete Arro $^{\mathrm{a} 1}$, Elina Malleus ${ }^{\mathrm{b}}$, Juta Jaani ${ }^{\mathrm{c}}$, Anu Olvik ${ }^{\mathrm{d}}$ \\ a Tallinna Ülikooli haridusteaduste instituut \\ ${ }^{b}$ Tallinna Ülikooli loodus- ja terviseteaduste instituut \\ ${ }^{c}$ Tartu Ülikooli majandusteaduskond \\ ${ }^{d}$ Eesti Ettevõtluskõrgkool Mainor
}

\begin{abstract}
Annotatsioon
Ettevõtlikkuse ja ettevõtluspädevuse toetamiseks on loodud mitmeid programme (Junior Achievementi õpilasfirmade programm, ettevõtlusteater, ettevõtlike koolide võrgustik, ettevõtlusõppe valikaine), mis on eri rõhuasetusega ning milles kasutatakse eri meetodeid. Seetõttu on oluline kirjeldada programmide tähendust ja erisusi ettevõtlikkuspädevuse arendamise kontekstis. Artiklis võetakse vaatluse alla enamik Eesti ettevõtlusprogramme, käsitledes neid vähe uuritud perspektiivist: milline on programmide mõju arenguuskumustele ning sotsiaalsetele oskustele? Uuringu valimisse kuuluvad üldhariduskoolide 8. klasside õpilased, kes kas osalevad (sekkumisgrupp, $N=198$ ) või ei osale ettevõtlusõppe programmides (kontrollgrupp, $N=125$ ). Õppijaid hinnatakse arenguuskumuste ja enesehinnanguliste sotsiaalsete oskuste alusel enne ja pärast ettevõtlusõppe programmis osalemist. Tulemused viitavad, et arenguuskumustes ja enesehinnangulistes sotsiaalsetes oskustes ei ilmne erinevusi ei enne ega pärast programmis osalemist, eri programmide ega sekkumis- ja kontrollgrupi vahel. Samuti ei ilmne eri võimekusega õpilaste rühmade vahel uuritud näitajate puhul statistiliselt olulisi erinevusi. Üks võimalik selgitus tulemustele on, et motivatsiooni või sotsiaalsete oskustega seotud alapädevusi ei teadvustata ettevõtluspädevuse osana. Tulemused osutavad võimalustele, kuidas saaks ettevõtlusprogrammide õpetajaid ja õppijaid senisest veelgi paremini toetada, näiteks aidates ettevõtlikkuspädevust alapädevuste kaupa mõtestada.
\end{abstract}

Võtmesõnad: ettevõtlusõpe põhikoolis, ettevõtlikkuse ja ettevõtluspädevuse arendamine, arenguuskumused, enesehinnangulised sotsiaalsed oskused 


\section{Sissejuhatus}

Ettevõtlikkust ja ettevõtluseks valmisolekut ${ }^{2}$ toetatakse Eesti koolides peale riiklikes õppekavades kirjeldatud võimaluste (Põhikooli riiklik õppekava, 2011) ka õppekavavälise tegevuse kaudu, rakendades eri programme, nt õpilasfirmade programm Junior Achievement Eesti, ettevõtliku õppe ja koolisüsteemi integreerimise haridusprogramm „Ettevõtlik kool“, samuti eraalgatuste kaudu, nt ettevõtlust, majandust ja rahatarkust edendav rollimäng „Ettevõtlusküla“ ning ettevõtluse ja ettevõtlikkuse õpetamise aktiivõppe metoodika „Ettevõtlusteater“. 2016. aastal kutsus haridus- ja teadusministeerium ettevõtlikkuse ja ettevõtlusõppe süsteemseks arendamiseks ellu ettevõtlusõppe programmi „Edu ja tegu“. Arvestades ettevõtlust toetavate algatuste suurt hulka, on oluline aru saada, kuidas eri ettevõtlusõppe vormid toetavad ettevõtlikkuse kujundamist ja ettevõtluseks valmisolekut ning milline on eri tegevuste mõju õpilastele. Sel eesmärgil tehtigi ettevõtlusõppe programmi raames eri ettevõtlusprogrammide efektiivsuse hindamise uuring.

Haridusliku sekkumise korral ${ }^{3}$, iseäranis ettevõtlikkuse kontekstis, on ootuspärane hinnata programmide efektiivsust seatud eesmärkide saavutamisel. Ettevõtlusõppe programmi efektiivsuse hindamise uuring peaks ideaalis hõlmama sekkumis- ja kontrollgrupi õpilaste põhjalikku ning mitmekesist hindamist (mitte üksnes enesehinnanguliste skaalade, vaid ka testide, probleemülesannete, teiste hinnangute jms kasutamist) nii enne kui ka korduvalt pärast programmis osalemist, sh haridusasutuse lõpetamise järel, sest alles siis avaldub potentsiaalselt ettevõtlik käitumine kõige tõenäolisemalt. Selline uuring oleks

Artiklis kasutatakse eri termineid, mis vajavad selgitust. Ettevõtlikkuspädevusest räägitakse siis, kui kõne all on põhikooli riikliku õppekava üldpädevus, mida peavad võrdväärselt arendama kõik üldhariduskoolid. Selle mõiste all peetakse silmas pigem kooliajal ehk üldjuhul enne ettevõtlusega tegelemist arendatavat üldpädevust, mis on vajalik mitmekesisemates kontekstides (pere, koolielu, kogukond jne) kui ettevõtlus. Ettevõtluspädevus on aga eelnevast avaram mõiste ja seda kasutatakse kontekstis, mis on seotud praeguse uurimuse raamistikuga ehk programmiga „Edu ja tegu“. Selle programmi raames loodi ettevõtluspädevuse mudel, mis hõlmab nii üldhariduse mõistes ettevõtlikkuspädevust kui ka spetsiffiliselt ettevõtlusega seotud teadmisi-oskusi. Ettevõtlusprogrammi all peetakse silmas üldhariduskoolidele mõeldud õppekavaväliseid programme, mille kaudu toetatakse ettevõtluseks ja ettevõtlikkuseks vajalike oskuste, teadmiste ja hoiakute arengut. Terminoloogilised erinevused on paratamatud, sest uurimuse raamistikuks olevas programmis „Edu ja Tegu“ keskendutakse ettevõtluspädevuse arendamisele eri haridustasemetel, ühtlasi soovitakse jõuda selle mõiste sisus ühtsele arusaamale. Kui aga kõne all on üldhariduse kontekst, nagu praegusel juhul, on korrektne viidata põhikooli ja gümnaasiumi riiklikule õppekavale ning seega ettevõtlikkuspädevusele, mis küll sisaldub ettevõtluspädevuses, kuid ei kattu sellega tervenisti.

3 Sekkumise all mõeldakse psühholoogiauurimustes laialdaselt levinud terminit intervention (study), mis viitab üldjuhul teoreetiliselt põhjendatud muutusele, tegevusele, õppeviisile vms, mida kontrollitud tingimustes ja eelistatavalt kontrollgrupiga võrdluses mingil valimil uuritakse. 
aga üsna ressursimahukas. Kuna siinse uurimuse raames on ressursside hulk piiratud, võetakse eesmärgiks hinnata pikilõikeliselt Eestis rakendatavate ettevõtlusprogrammide efektiivsust ettevõtluspädevuse osakomponentide arendamisel, kogudes andmeid vaid kahel korral. Teisisõnu soovitakse välja selgitada, kas pärast programmide läbimist on sekkumisgrupi ettevõtlikkuspädevuse alapädevused muutunud kontrollgrupiga võrreldes ootuspärases suunas. Artiklis kajastatakse vaid osa laiemas uuringus hinnatud muutujatest, keskendudes arenguuskumustele ning enesehinnangulistele sotsiaalsetele oskustele, mida võib pidada ettevõtliku käitumise olulisteks alapädevusteks.

\section{Ettevõtlikkus kui üldpädevus}

Üldpädevustena mõistame psüühiliste protsesside - teadmiste, oskuste, motivatsiooni, uskumuste, hoiakute - kogumit, mis on vajalik toimetulekuks mingis tegutsemisvaldkonnas (Kikas, 2015). Mõned üldpädevused, nagu sotsiaalne, enesemääratlus- või õpipädevus, on elementaarsemad, teised, nagu kodanikuvõi ettevõtlikkuspädevus, paiknevad hierarhiliselt kõrgemal, toetudes elementaarsematele üldpädevustele ning hõlmates lisaks spetsiifilisi, nt ettevõtluskeskkonnaga suhestumise oskusi ja teadmisi. Seega on üldpädevustel kattuvaid komponente, nt on probleemilahendusoskus nii sotsiaalse, ettevõtlikkus- kui ka õpipädevuse osa. Samas ei ole kattuvusest hoolimata mõistlik olulisi komponente ühestki üldpädevusest välja arvata, oletades, et neid toetatakse mõne teise üldpädevuse arendamise kaudu. Õpilaste üldpädevuste arendamine on olnud järjepidevalt ka riikliku õppekava prioriteet (Põhikooli riiklik õppekava, 2011) ning üldpädevuste olemust on mõtestatud, uuritud ja nende hindamiseks vajalikke vahendeid loodud mitmes projektis, nt projekt „Üldpädevused ja nende hindamine“ (2011-2014, projekti nr S10012, projekti juht prof Eve Kikas).

Kuigi ettevõtlikkuspädevust võib defineerida mitmeti (Põhikooli riiklik õppekava, 2011; Venesaar et al., 2018; Õunapuu \& Ots, 2015), rõhutatakse definitsioonides üsna sarnaseid aspekte: ettevõtlikkuspädevus on kogum spetsiifilisemaid kompetentse, mis võimaldavad oma käitumist ja motivatsiooni sihipäraselt suunata, loomaks koostöiselt väärtusi ja lahendamaks probleeme, tuginedes seejuures ettevõtlusega seotud teadmistele ning jätkusuutlikkust rõhutavatele väärtustele. Näiteks on programmi „Edu ja tegu“ ühe tegevusena loodud ettevõtluspädevuse mudel, mis põhineb sarnastel mujal koostatud raamistikel. Selle järgi koosneb ettevõtluspädevus neljast suuremast valdkonnast (Venesaar et al., 2018), mis jagunevad omakorda järgmisteks alakomponentideks:

1) enesejuhtimine: enda motivatsiooni suunamine, uskumused võimete arendatavuse kohta, emotsioonide reguleerimine, metatunnetus; 
2) väärtust loov mõtlemine ja probleemide lahendamine: pigem kognitiivsed protsessid - planeerimine, probleemilahendus, ka mõtlemise arengu tase ning sellega seotult oma tegevuse mõtestamine eetilisuse ja väärtuspõhisuse kontekstis;

3) sotsiaalsete olukordade lahendamine: suhtlemisoskused, koostöö, algatamine, kaasamine;

4) spetsiifilisemad teadmised äriideede elluviimisest: teadmised ärikeskkonna ja -võimaluste ning finantskirjaoskuse kohta.

Kuigi selline jaotus on teatud piirini tinglik, nt kognitiivsetele protsessidele tuginevad ka kõik teised protsessid, aitab mõningane lihtsustus keerukat üldpädevust paremini mõista ja struktureerida. Kuivõrd ettevõtlikkus on vajalik eelkõige kõrge määramatuse tasemega olukordades, mis eeldavad paindlikku reageerimist muutustele, on mõistetav, et nii keeruka üldpädevuse eeldus on küllaltki kompleksne kogum alakomponente.

Üldhariduse tasandil on ettevõtlikkust kui üldpädevust defineeritud mitte kitsalt kui enda või teiste majandusliku heaolu saavutamisega seotud pädevust, vaid laiemalt - ettevõtlik saab olla ka mõne rühma (kooli, pere, kogukonna) liikmena, ühisüritusi korraldades, probleeme lahendades või kellegi heaolu eest välja astudes (Õunapuu \& Ots, 2015). Kuigi enamik lapsi ei saa üldhariduse omandamise käigus proovida ettevõtlust selle traditsioonilises vormis - mis muudab üldhariduskoolis ettevõtlikkuse uurimise kitsalt ettevõtluse kontekstis põhjendamatuks -, on siiski võimalik hilisema ettevõtlustegevuse jaoks vajalikke oskusi, teadmisi ja omadusi arendada ka igapäevases koolielus ning jälgida nende arengut. Näiteks on mõistlik läbivalt toetada õpilastes püsivust ja vastupidavust olukordades, kus nad peavad end milleski proovile panema, kujundades nende arenguuskumusi, mis tulevad kasuks nii ettevõtlikkust eeldavas kui ka muus kontekstis.

Kuna üldpädevus on keerukas alakomponentide kogum ning seda ei saa, vähemalt mitte üldhariduse vältel, hinnata vaid ühe dimensiooni alusel, lähtutakse selle uurimisel ja hindamisel alakomponentidest. Ettevõtlikkuspädevuse hindamine ja arendamine komponentide kaupa ei tugine mitte ainult pedagoogilistele ja psühholoogilistele teadmistele pädevuste olemusest, vaid ka teadmistele ettevõtlusvaldkonnast. Ettevõtte edukus sõltub paljudest teguritest, mis on üksteisega keerukates vastastikseostes (Baron \& Markman, 2003; Man, Lau, \& Snape, 2008) ning mille hulgas on tulevase ettevõtja pädevused ühed olulisimad. Ka ettevõtlusvaldkonnas pööratakse tänapäeval aina enam tähelepanu edenemist ja arengut toetavatele teguritele, mis võivad esineda vähem või rohkem implitsiitsel kujul, nagu püsivus ja arenguuskumused (Johnston, 2017) või sotsiaalsed oskused (Lans, Blok, \& Gulikers, 2015). 


\section{Uuringus hinnatud ettevõtlikkuspädevuse komponendid}

Artiklis analüüsitakse osa ettevõtlusprogrammide mõju-uuringus uuritud alapädevustest. Analüüsitud alapädevused kuuluvad enesejuhtimise ja sotsiaalsete olukordade lahendamise valdkonda, jagunedes arenguuskumusteks võimekuse ja loovuse kohta ning sotsiaalseteks oskusteks.

\section{Arenguuskumused võimekuse ja loovuse kohta}

Arenguuskumustele keskendutakse artiklis eelkõige seetõttu, et need mõjutavad käitumist olukordades, mis nõuavad pingutamist ja eeldavad enese proovilepanekut (Blackwell, Trzesniewski, \& Dweck, 2007). Arenguuskumuste teooria kohaselt, milles käsitletakse inimeste uskumusi võimete ja võimekuse arendatavuse kohta, erinevad õpilased oma uskumuste laadi poolest: nad kalduvad kas arvama, et võimed on pigem muutumatud, püsivad suurused (jäävususkumus, fixed mindset) või et need on arendatavad (juurdekasvuuskumus, growth mindset) (Dweck \& Leggett, 1988; Molden \& Dweck, 2006; Rattan, Savani, Naidu, \& Dweck, 2012). Uuringud näitavad, et uskumine võimete arendatavusse on seotud paremate tulemusteni viiva käitumisega (Blackwell et al., 2007; Mueller \& Dweck, 1998; Yeager et al., 2016), nt pingutamine ja keskendumine õppimise ja saavutuste kontekstis, vajaduse korral strateegiate vahetamine, abi küsimine, eksimise ees hirmu puudumine ning uudishimu iseenda vigade põhjuste vastu. Kõik need käitumisviisid on olulised ka ettevõtlusega tegelemisel. Kui õppijas domineerib pigem jäävususkumus - arusaam, et võimed on kaasa sündinud ning neid ei saa elu jooksul kuigivõrd muuta -, siis kaasneb sellega üldjuhul hoiak, et pingutamisest ei ole kasu. Lisaks võib õppija arvata, et kui asjad kerge vaevaga ja suhteliselt kiirelt ei õnnestu, siis pole mõtet proovida ega vaeva näha, kuna selles valdkonnas pole ta piisavalt võimekas. Tulemuseks võib olla tagasihoidlikum edenemine õppetöös, mis on tõenäoliselt tingitud pigem jäävususkumusega seotud õpikäitumisest, mitte potentsiaali reaalsest puudumisest (Blackwell et al., 2007).

Kuigi ettevõtluspädevus koosneb eri alaosadest, mis kõik on terviku mõttes olulised, võib arenguuskumusi käsitleda ühe oskuste ja teadmiste omandamise edukuse eeldusena. Nimelt kui õpilane kaldub uskuma, et tegevusvaldkond ettevõtlus - ei ole midagi tema jaoks või ta pole loomult ettevõtja, on sellest mõjutatud ka tema pingutamiskäitumine. Kuna üks ettevõtlusprogrammide eesmärke on toetada ettevõtlikku hoiakut ja motivatsiooni, on tähtis uurida, kas uskumused võimete arendatavuse kohta muutuvad süsteemsete ettevõtlusprogrammide läbimise jooksul. Uuringud eri haridustasemetel põhiharidusest (Romero, Master, Paunesku, Dweck, \& Gross, 2014) kõrghariduseni (Yeager et al., 2016) näitavad, et arenguuskumused avaldavad õpitulemustele ja vastu- 
pidavusele soodsat mõju olukordades, mis eeldavad õppijalt pingutust. Ka juhtimises ja ettevõtluses tähtsustatakse aina enam arenguuskumuste rolli eduka ja paindliku tegevuse toetajana (nt Hogan \& Dweck, 2016; Hagel \& Brown, 2010; Keating \& Heslin, 2015; Murphy \& Dweck, 2010).

Eeltoodule lisaks on ettevõtluse kontekstis asjakohane uurida uskumusi loovuse arendatavuse kohta, kuna loovust peetakse ettevõtlusega seotud oluliseks omaduseks (Mylonas, Kyrgidou, \& Petridou, 2017). Ka varasematest selleteemalistest uurimustest ilmneb, et uskumused loovuse arendatavuse kohta on üks loovust ennustavaid tegureid (Karwowski, 2014). Seega keskendutakse siinses uurimuses ka loovusega seotud uskumustele.

On teada, et uskumused kujunevad keskkonnalt saadava tagasiside pinnalt. Seetõttu on põhjust arvata, et ka sekkumisprogrammide rakendajatel on võimalik suunata õppijate pingutamiskäitumise aluseks olevaid uskumusi. Luues õpikeskkonna, mis julgustab katsetama ja eksima, seab õppijatele suuri ootusi ning annab protsessi (strateegiate, pingutuse ja abi küsimise) kohta tagasisidet, on võimalik ettevõtlusprogrammidel toetada õppijate kujunemist püsivateks, edenemisele suunatud ning järk-järgult aina paremaid tulemusi saavutavateks tegutsejateks.

\section{Sotsiaalsed oskused}

Sotsiaalset pädevust defineeritakse mitmeti. Üks võimalik selgitus on, et sotsiaalne pädevus viitab nendele indiviidi jaoks kättesaadavate protsesside ja ressursside aktiivsele ning pädevale kasutamisele, mida on tarvis sotsiaalsetes situatsioonides ja kontekstides oma eesmärkide saavutamiseks ja olukorra nõudmistele vastamiseks (Iarocci, Yager, \& Elfers, 2007). Sotsiaalse pädevuse alaosa, sotsiaalsete oskuste hindamisel tuginetakse praeguses uurimuses SOCIAL-mudelile (vt Beauchamp \& Anderson, 2010), millest on eesti keeles ning põhikooliõpilaste valimi põhjal põhjalikumalt kirjutanud Kaldoja (2015). Selle mudeli alusel hinnatakse nelja sotsiaalse pädevuse komponenti, mis on eduka ja paindliku sotsiaalse suhtlemise puhul olulised (ehkki mitte ainukesed) komponendid. Esimene on prosotsiaalne käitumine, mis rajaneb nii mõistuseteoorial ehk inimese võimel mõista teiste inimeste meeleseisundeid kui ka empaatial ning väljendub teistele inimestele kasu toovas ja nende heaolu toetavas käitumises. Teine komponent on huumorimeel ehk oskus nalja mõista ja situatsiooni sobivat, teisi mittehaavavat nalja teha. Kolmas komponent on suhtlemisoskus, mis tugineb sotsiaalse info märkamisel, töötlusel ja tõlgendamisel, eesmärgi valimisel ja kogemusel põhineva või uuest olukorrast lähtuva vastuse genereerimisele. Neljas sotsiaalsete oskuste aspekt on enesekontroll, mis tähendab võimet esmast impulssi pidurdada, käituda eesmärgipäraselt ja planeeritult (Kaldoja, 2015). 


\section{Ettevõtlikkuspädevuse arendamine ja hindamine}

Kuigi ettevõtlusõpe on üks põhikooli riiklikus õppekavas kirjeldatud valikainetest ja see pole seega koolidele kohustuslik, on ettevõtlikkuspädevuse kui üldpädevuse arengu toetamine koolide õppekavajärgne kohustus (Põhikooli riiklik õppekava, 2011). Hoolimata sellest, et üldpädevuste teaduslik mõtestamine ja uurimine on Eestis küllaltki lühikese ajalooga, on üldpädevuste arengut toetatud koolides juba mõnda aega, millest annavad tunnistust nii koolide pakutavad valikained kui ka õppekavavälised tegevused ja programmid. Seejuures on erinevad üldpädevused saanud tõenäoliselt eri määral tähelepanu, nt on ettevõtlikkuspädevuse arendamisele pühendatud (võimalik et ajaloolispoliitilistel põhjustel) vähemalt neli programmi ja nende elluviimisel on tehtud haridusasutustega pikka aega koostööd. Need pakuvad õpilastele tegevusi, mis toetavad ettevõtlikkusega seotud oskuste arengut, kuid mis üldharidusprogrammis sellises mahus ei sisaldu. Näiteks on koolidel võimalik kasutada ettevõtlusaines Junior Achievementi, „Ettevõtliku kooli“ või „Ettevõtlusteatri“ programme või koostada ise koolile sobiv ettevõtlusõppe valikaine.

Ettevõtlusõppe programmid on oma olemuselt erinevad. Junior Achievement arendab noortes ettevõtlikkust ja kujundab majanduslikult mõtlevaid inimesi ning pakub ettevõtlusprogramme kõigi vanuseastme õpilastele. Ettevõtlusõpet toetavad ka organisatsiooni korraldatavad õpilasüritused. Junior Achievementi programmi kasutab rohkem kui 200 kooli ( vt http://www.ja.ee/ meist). Seevastu „Ettevõtlik kool“ on mõeldud ettevõtliku õppe integreerimiseks koolisüsteemi ning selle eesmärk on kujundada ettevõtlikku hoiakut õppetöö kaudu, toetudes riiklikule õppekavale. „Ettevõtliku kooli“ standardile vastab 13 kooli (vt http://evkool.ee/ettevotlik-kool/). „Ettevõtlusteater“ on aga muutuvat keskkonda arvestav ja noortele sobiv ettevõtlikkuse ja ettevõtluse õpetamise metoodika (vt http://ettevotlusteater.eu/). Eeltoodust ilmneb, et juba programmide kirjelduses väljenduvad nende erinevad rõhuasetused ja lähenemisviisid - alates ühe meetodi pakkumisest kuni kogu kooli hõlmava hoiakute kujundamiseni. Seega on peale teiste aspektide oluline analüüsida ka kasutatavate programmide või valikainete erinevusi (olgugi et need jäävad praeguse uuringu fookusest välja). Kuigi ettevõtlusõpet on võimalik rakendada mitmel viisil, sarnanevad uuringus osalevates koolides rakendatavad ettevõtlusõppe programmid üksteisega selle poolest, et kõik need püüavad toetada ettevõtlikkuse komponente.

Tavapärane on, et haridusliku sekkumise puhul püütakse hinnata selle oodatavat mõju õppijatele (Durlak, Weissberg, Dymnicki, Taylor, \& Schellinger, 2011; Elert, Andersson, \& Wennberg, 2015), mõistmaks, kas ja kuivõrd toetab iga konkreetne programm neid omadusi, mida väidab end toetavat. Kuigi mõningaid Eestis rakendatavaid ettevõtluse arendamise programme on 
korduvalt uuritud (nt Innovation Clusters for Entrepreneurship Education), võib siiski oletada, et senistest uuringutest ei piisa kõigi ettevõtlusprogrammide kohta ammendavate järelduste tegemiseks. Seda seisukohta toetavad allesitatud mõttearendused.

Esiteks, ettevõtlikkuspädevuse - nagu ka teiste üldpädevuste - mõtestamine, hindamine ja arendamine alapädevuste ning -komponentide kaupa on Eestis küllaltki uus praktika (Kikas, 2015). Programmi „Edu ja tegu“ raames arendati edasi senist üldhariduse ettevõtlikkuspädevuse kontseptsiooni (Põhikooli riiklik õppekava, 2011; Õunapuu \& Ots, 2015) ning koostati teoreetiline mudel kõigist komponentidest, mis on ettevõtlikkuspädevuse avaldumise mõttes eeldatavalt olulised (Venesaar et al., 2018). Seega võiks olla just nüüd, mil on valmis saanud uus haridustasemete ja -liikide ülene ettevõtluspädevuse mudel, asjakohane uurida, kuidas üldhariduse ettevõtlusprogrammid toetavad ettevõtluspädevuse alakomponentide arengut. Selline analüüs aitab paremini mõista, millistes pädevusmudeli alaosades on õpetajatel ja koolitajatel piisav kompetentsus ning millistes osades saab õpetajaid ja programmide koostajaid veelgi enam toetada.

Teiseks, praegu koolides kasutatavaid ettevõtlusprogramme pole analüüsitud üheski terviklikus võrdlusuuringus. See on mõistetav, sest kõiki programme hõlmav uuring, eelkõige sobivate hindamisvahendite loomine, katsetamine ja valideerimine, on mahukas töö. Programm „Edu ja tegu“ võimaldas sõnastada programmideülese uurimisküsimuse ning pakkus samas uue ja täiustatud ettevõtluspädevuse raamistiku - määratluse, millistes teadmistes, oskustes, hoiakutes, käitumisviisides jm kõnesolev pädevus väljendub. See andis ka selgema teoreetilise aluse sobivate hindamisvahendite valimiseks või loomiseks. Ettevõtlusprogrammide võrdlevas pikiuuringus lähtutigi nimetatud teoreetilisest mudelist (vt Venesaar et al., 2018). Siinses artiklis keskendutakse pädevusmudeli nn pehmete oskuste aspektidele: mõningatele pingutamiskäitumisega (uskumused) ja sotsiaalsete oskustega seotud teguritele. Sellise valiku tegemisel lähtuti eeldusest, et ettevõtlusprogrammid võivad läbivalt toetada ka motivatsiooniga seotud ettevõtlikkuse aspekte, suunates õpilasi kohaste võimekususkumuste poole, nt väärtustades pingutust ja eksimist kui õppimise loomulikke osi. Samas pole teadaolevalt võimekusega seotud uskumusi ettevõtlusprogrammides otsesõnu rõhutatud ning ilma neid teadvustamata ei pruugi uskumused kohasemaks muutuda. Samuti on sotsiaalsed oskused ettevõtlusprotsessis vältimatult vajalikud, ehkki nende teadlik mõtestamine ja arendamine ei pruugi olla otseselt ettevõtlusprogrammi fookuses. Siinses artiklis keskendutaksegi nende näitajate võimalikule arengule ettevõtlikkusprogrammides. 


\section{Eesmärk ja uurimisküsimused}

Artiklis eeldatakse, et ettevõtlusprogrammidel võib olla toetav mõju ettevõtluspädevuse alakomponentidele. Sel eesmärgil sõnastati järgmised uurimisküsimused.

1. Kas ettevõtlusprogrammides osalevate õpilaste uskumused võimekuse ja loovuse arendatavuse kohta ning enesehinnangulised sotsiaalsed oskused muutuvad programmi vältel enam kui kontrollgrupi õpilastel?

2. Kas eri ettevõtlusprogrammides osalevate õpilaste uskumused võimekuse ja loovuse arendatavuse kohta ning enesehinnangulised sotsiaalsed oskused muutuvad eri määral?

3. Kas uuritud õpilaste hulgas (nii sekkumis- kui ka kontrollgrupis) on alagruppe, kes edenevad hinnatud aspektide poolest teistest õpilastest erinevalt? Tõenäoliselt on uudsetes situatsioonides, mida ettevõtlusprogrammides harjutatakse, vaja teha mitmesuguseid keerukaid tegevusi: töödelda uut infot, rakendada teadmisi, langetada otsuseid, jälgida oma tegevust jne. Seejuures võivad edukamaks osutuda kognitiivselt võimekamad õpilased. Seepärast uuritaksegi, kas kognitiivselt võimekamad õpilased edenevad hinnatud komponentide poolest ettevõtlusprogrammis teistest õpilastest erinevalt. Kuna eesmärk on välja selgitada õppe tulemuslikkus ehk jälgida muutust, mis avaldub vaid ajas, siis tehti pikiuuring - õpilasi hinnati nii enne kui ka pärast ettevõtlusprogrammis osalemist. Et mõista, kas eeldatavat muutust saab seostada läbitud programmiga või õpilaste loomuliku küpsemise ja tavapärase kooliprogrammiga, kaasati uuringusse sekkumisgrupiga võimalikult võrreldav kontrollgrupp.

\section{Metoodika}

\section{Meetod ja valim}

Pikiuuring koosnes kahest andmekogumisetapist, millest esimene toimus 2016. aasta sügisel ning teine 2017. aasta kevadel. Andmeid koguti eri ettevõtlusprogramme rakendavates koolides ning kontrollgrupi koolides, kus õpilased ei läbinud uuringuperioodil ettevõtlusprogrammi või -ainet, samuti ei olnud uuritavad seda teadaolevalt ka varem läbinud. Vanuseastme valimisel lähtuti soovist võrrelda programmides osalevaid lapsi omavahel. Arutelu uuritavate ettevõtlusprogrammide juhtidega kinnitas, et programmide lõikes on kattuv vanusegrupp 8. klass.

Uuringu valimi moodustasid 8 . klasside õpilased $(N=323)$ üle Eesti, sh eri piirkonnad, maa- ja linnakoolid, eri suurusega koolid, mis on liitunud mõne ettevõtlusprogrammiga või kuulusid kontrollgruppi. Vastanute keskmine vanus 
oli 14,11 $(S D=0,36)$ ning 46\% vastanutest olid tüdrukud. Sekkumisgruppi kuulusid klassid, kus rakendati kas ühte kolmest ettevõtlusprogrammist (tabel 1, programmid 1, 2, 3), kahe programmi kombinatsiooni (tabel 1, programm 4) või kooli enda väljatöötatud ettevõtluse valikainet (tabel 1, programm 5). Tabelis 1 on esitatud uuritavate koolide arv ning tabelis 2 sekkumis- ja kontrollgrupi õpilaste jaotus linna- ja maakoolide vahel. Kokku oli sekkumisgrupis kümme kooli. Kontrollgrupi moodustasid viie kooli õpilased: kaks puhtalt kontrollkooli ja kolm sellist kooli, kus üks klass või osa lastest osales programmis ning ülejäänud moodustasid kontrollgrupi.

Valimi koostamisel võeti arvesse programmide rakendamise kogemust: uuringusse valiti vaid need koolid, kus õpetajad olid varem programmi rakendanud. Koolide valimisel konsulteeriti programmide koordinaatoritega, et võimaluse korral leida sellised koolid, kus õpetajatel oleks programmiga juba mõningane kogemus. Teisisõnu sooviti leida õpetajad, kes alles ei katsetaks programmi. Samuti jälgiti, et sekkumisgrupi õpilased ei oleks saanud varasemates klassides ettevõtlusprogrammidega seotud õpet, mis oleks teinud keerukaks nende algtaseme võrdlemise kontrollgrupi omaga. Koolide ja programmide konfidentsiaalsuse tagamiseks ei esitata neid uurimuses nimeliselt.

Tabel 1. Uuringus osalevate koolide arv

\begin{tabular}{lc}
\hline Programm & Arv \\
\hline Programm 1 & 3 \\
\hline Programm 2 & 3 \\
\hline Programm 3 & 1 \\
\hline Programm 4 (1. ja 2. programm) & 2 \\
\hline Programm 5 & 1 \\
\hline Kontrollgrupp* & 2 \\
\hline Kokku & 12 \\
\hline
\end{tabular}

* Märkus. Kontrollgrupp on joonistel grupp 6.

Tabel 2. Uuritavate arv $(N)$ programmide ja piirkondade kaupa

\begin{tabular}{lccccccc}
\hline & $\begin{array}{c}\text { Prog- } \\
\text { ramm 1 }\end{array}$ & $\begin{array}{c}\text { Prog- } \\
\text { ramm 2 }\end{array}$ & $\begin{array}{c}\text { Prog- } \\
\text { ramm 3 }\end{array}$ & $\begin{array}{c}\text { Programm } \\
\mathbf{4}(\mathbf{1}+2)\end{array}$ & $\begin{array}{c}\text { Prog- } \\
\text { ramm 5 }\end{array}$ & $\begin{array}{c}\text { Kontroll- } \\
\text { grupp (6) }\end{array}$ & Kokku \\
\hline Linn & 62 & 25 & 22 & 17 & - & 102 & 228 \\
\hline Maa & 4 & 34 & - & 25 & 9 & 23 & 95 \\
\hline Kokku & 65 & 49 & 19 & 40 & 9 & 125 & 323 \\
\hline
\end{tabular}




\section{Hindamisvahendid}

\section{Üldvõimekus}

Õpilaste üldvõimekust hinnati Raveni testi (E-osa) abil. Üldvõimekuse näitaja lisati hindamisvahendisse eesmärgiga välja selgitada, kas õpilase üldvõimekuse tase võib vahendada ettevõtlusprogrammide mõju. Näiteks võivad võimekamad õpilased eri osaoskusi eeldavast koolivälisest programmist enam võita ning saada motiveerivama kogemuse kui nõrgemad õpilased. Seega saab taustategurit arvestades uurida, kas ettevõtlusprogramm toetab kõiki õpilasi sarnaselt või eristuvad mõned alagrupid üksteisest ning kas eeldatav mõju on seotud õpilase individuaalsete erinevustega. Näiteks võib osas programmides valim osutuda kallutatuks põhjusel, et osalemine oli vabatahtlik (nn self-selection bias ehk võimalus end ise valimisse valida, mis võib valimit mõningate omaduste, sh võimekuse poolest moonutada, vt ka nt Johansen, 2017). Raveni testi reliaablusnäitaja (Cronbachi alfa) oli 0,92.

\section{Uskumused võimekuse ja loovuse arendatavuse kohta}

Uskumusi võimekuse arendatavuse kohta uuriti Ausi loodud kuueväitelise hindamisvahendiga, mis on koostatud projekti „Üldpädevused ja nende hindamine, 2011-2014“" raames (vt lähemalt Aus \& Jõgi, 2014) ning mille puhul on tuginetud varasematele võimekususkumuste skaaladele (Dweck \& Leggett, 1988; Schommer, 1990; Schommer-Aikins, 2004). See hindamisvahend võimaldab anda vastuseid viiepalliskaalal, kus 1 - „ei ole üldse nõus“ ja 5 - „olen täiesti nõus“. Üks tüüpiline väide on järgmine: „Võimekus on omadus, mida ei saa koolis õppimisega eriti muuta." Skaala reliaablusnäitaja oli esimesel andmekogumisel 0,64 ja teisel 0,76.

Loovusega seotud uskumusi hinnati Karwowski (2014) loovususkumuste hindamise vahendiga (10 väidet) viiepalliskaalal, kus 1 - „ei ole üldse nõus“ ja 5 - „olen täiesti nõus“. Skaala struktuuri kontrolliti peakomponentide meetodil tehtud faktoranalüüsiga, kasutades Promaxi pööramist. Saadud tulemused sarnanesid originaalhindamisvahendi omadega. Nii eel- kui ka järelandmekogumil eristus kaks faktorit: loovusega seotud jäävususkumused ja loovusega seotud juurdekasvuuskumused. Kõige parema kirjeldusvõimega mudel saadi kaheksaväitelise skaalaga (eelandmekogumil kirjeldusvõime 46\% ja järelandmekogumil 52\%), seega jäeti välja kaks väidet, mis laadusid mõlemasse faktorisse. Näide eelandmekogumil saadud lõpliku faktoranalüüsi tulemuste kohta on esitatud lisas. Artikli aluseks olevas uuringus kasutati edasistes analüüsides vaid jäävususkumustega seotud alamfaktori nelja väite keskmist skoori, sest see alamfaktor eristas kirjeldavate eelanalüüside kaudu uuritavaid kõige paremini (nt väide „Mõned inimesed lihtsalt on loovad ja teised mitte. 
Harjutamine seda ei muuda“). Loovusega seotud jäävususkumuste alaskaala reliaablusnäitaja oli esimesel andmekogumisel 0,58 ja teisel 0,71 .

\section{Sotsiaalsed oskused}

Sotsiaalsete oskuste hindamiseks kasutati neljapallise vastuseformaadiga (1 „üldse ei iseloomusta“, 4 - „iseloomustab peaaegu alati“) 11väitelist skaalat, mis tugineb Beauchampi ja Andersoni (2010) sotsiaalse toimetuleku mudelile SOCIAL ning mille on Eesti konteksti kohandanud Kaldoja. Ühtlasi on Kaldoja (2014) näidanud skaala head sobivust sotsiaalsete oskuste hindamiseks. Skaala reliaablusnäitaja oli esimesel andmekogumisel 0,66 ja teisel 0,72 .

\section{Protseduur ja andmeanalüüs}

Ajavahemikus aprillist augustini 2016 valiti koostöös ettevõtlusõppe programmide koordinaatoritega uuringusse koolid ning lepiti kokku testimisaeg. Septembris peeti läbirääkimisi koolidega testi tegemiseks konkreetsetes klassides. Esimene andmekogumine koolides toimus 2016. aasta sügisel (oktoobernovember). Kuna kõiki hindamisvahendeid oli varem katsetatud, siis prooviuuringut ei tehtud: selle ainuke eesmärk oleks olnud hinnata, kui pikalt õpilastel testi täitmine aega võtab, mistõttu katsetati ajakulu mõõtmist mõne sobivas eas kooliõpilase peal. Andmekogumine planeeriti nii, et ettevõtlusprogrammi tegevused ei oleks sekkumiskoolides veel alanud, et hinnata programmist tulenevat võimalikku muutust. Uuringuks lepiti sekkumis- ja kontrollkoolidega kokku sobiv aeg ning küsiti õpilaste vanematelt e-kooli kaudu nõusolek lapse osalemiseks uuringus. Uuring (paberi ja pliiatsiga testipakett) tehti ühe uurija juhendamisel klassiruumis kahe koolitunni jooksul. Esmalt tutvustas uurija uuringu tausta, samuti uuringu vajalikkust ja seost ettevõtlusõppega. Õpilastel oli võimalik uuringust keelduda. Uuringu tegemise ajal toetas uurija õpilasi, kes soovisid saada abi või mõnda küsimust täpsustada. Õpilastel oli küsimustiku lõpus võimalik anda tagasisidet küsimustiku kohta või teha ettepanekuid. Õpilasi tänati pärast uuringut ning neile kingiti ettevõtlikkust toetav õpivahend. Aprillist juunini 2017 toimus samades koolides teine andmekogumisetapp, kus kasutati sama hindamisvahendite paketti, v.a Raveni üldvõimekuse test.

Andmete analüüsimisel kasutati kirjeldavat statistikat, reliaablusanalüüsi, eksploratiivset faktoranalüüsi, korrelatsioon- ja dispersioonanalüüsi. Andmeid analüüsiti programmidega Statistica 7.0 ja SPSS Statistics 24. 


\section{Tulemused}

\section{Sekkumis- ja kontrollgrupi õpilaste võrdlus esimese andmekogumisetapi järel}

Uuringu esimese andmekogumisetapi järel kontrolliti, kas sekkumis- ja kontrollgrupi õpilastel on hinnatud näitajate algtase sarnane või erinev. Ilmnes, et kontrollgrupi õpilaste Raveni testi tulemus oli oluliselt parem sekkumisgrupi omast $(t=-5,73, p=0,00)$. Võimekuse $(t=0,39, p>0,05)$ ja loovuse $(t=0,54$, $p>0,05)$ muudetavusega seotud uskumustes ning enesehinnangulistes sotsiaalsetes oskustes $(t=0,04, p>0,05)$ eeltestimisel sekkumis- ja kontrollgrupi vahel statistiliselt olulist erinevust ei ilmnenud.

\section{Üldvõimekuse, uskumuste ja enesehinnanguliste sotsiaalsete oskuste kirjeldav statistika ning korrelatsiooniseosed}

Tabelis 3 on esitatud uuritud tunnuste kirjeldav statistika ning nendevahelised seosed. Ootuspäraselt ei seostu üldvõimekuse näitaja ei uskumuste ega sotsiaalsete oskustega, samuti on ootuspärane, et uskumuste skoorid (suurem skoor näitab suuremat jäävususkumust) seostuvad läbivalt eri hetkedel ning võimekusekohased jäävususkumused seostuvad negatiivselt sotsiaalsete oskustega.

Tabel 3. Kirjeldav statistika ja korrelatsiooniseosed uuritud näitajate vahel

\begin{tabular}{|c|c|c|c|c|c|c|c|c|}
\hline & $M$ & $S D$ & 1 & 2 & 3 & 4 & 5 & 6 \\
\hline 1. Raven & 5,47 & 3,85 & - & & & & & \\
\hline $\begin{array}{l}\text { 2. Uskumused võimekuse } \\
\text { kohta (eeltest) }\end{array}$ & 2,28 & 0,58 & $-0,04$ & - & & & & \\
\hline $\begin{array}{l}\text { 3. Uskumused võimekuse } \\
\text { kohta (järeltest) }\end{array}$ & 2,34 & 0,69 & $-0,18$ & $0,54^{*}$ & - & & & \\
\hline $\begin{array}{l}\text { 4. Uskumused loovuse kohta } \\
\text { (eeltest) }\end{array}$ & 2,50 & 0,64 & 0,09 & $0,53^{*}$ & $0,33^{*}$ & - & & \\
\hline $\begin{array}{l}\text { 5. Uskumused loovuse kohta } \\
\text { (järeltest) }\end{array}$ & 2,51 & 0,70 & $-0,02$ & $0,41^{*}$ & $0,58^{*}$ & $0,45^{*}$ & - & \\
\hline 6. Sotsiaalsed oskused (eeltest) & 2,87 & 0,39 & 0,07 & $-0,22^{*}$ & $-0,31^{*}$ & $-0,09$ & $-0,15$ & - \\
\hline $\begin{array}{l}\text { 7. Sotsiaalsed oskused (järel- } \\
\text { test) }\end{array}$ & 2,96 & 0,41 & 0,15 & $-0,27^{*}$ & $-0,27^{*}$ & $-0,06$ & $-0,13$ & $0,69^{*}$ \\
\hline
\end{tabular}

Märkus. * - statistiliselt oluline nivool 0,05. 


\section{Uskumused võimekuse arendatavuse kohta eri programmide võrdluses}

Et analüüsida muutusi eri ettevõtlusprogrammides osalenud õpilaste uskumustes võimete arendatavuse kohta, tehti kordusmõõtmisega dispersioonanalüüs. Jooniselt 1 on näha, et erinevused gruppide vahel ja ka võrdluses kontrollgrupiga (grupp 6) ei ole ei esimesel ega teisel andmekogumisel olulised $\left(F(5,226)=0,75, p>0,05, \eta^{2}=0,02\right)$. Seega ei saa nende andmete põhjal väita, et eri ettevõtlusprogrammides osalemine suunaks õpilasi enam arenguuskumusi omaks võtma.

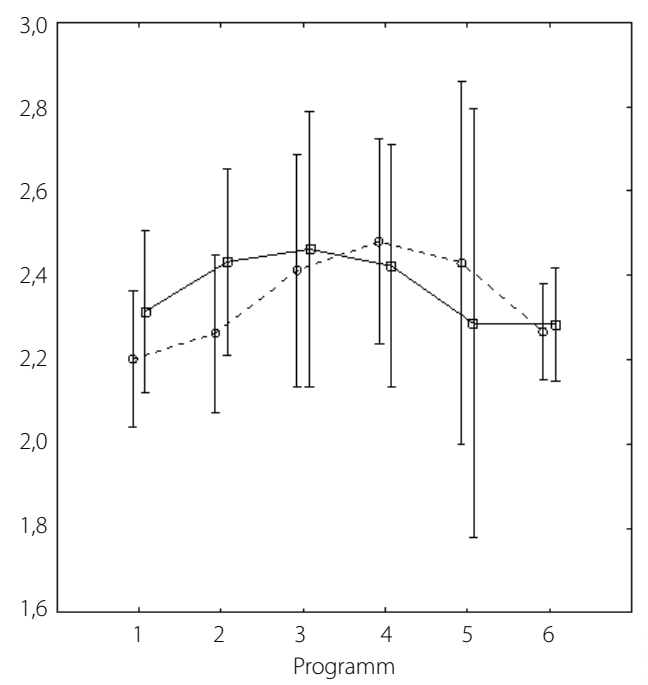

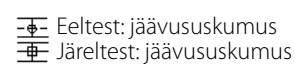

Joonis 1. Uskumused võimekuse arendatavuse kohta sekkumis- ja kontrollgrupis eri ettevõtlusprogrammide rakendamise eel ja järel (suurem skoor näitab suuremat jäävususkumust)

\section{Uskumused loovuse arendatavuse kohta eri programmide võrdluses}

Kordusmõõtmisega dispersioonanalüüsi rakendati ka õpilaste loovusega seotud jäävususkumuste analüüsimiseks, et uurida, kas ettevõtlusprogrammis osalemine on tekitanud muutusi loovuse arendatavusega seotud uskumustes ning kas need muutused on ettevõtlusprogrammiti erinevad. Ka loovusega seotud uskumustes ei ilmnenud muutust, s.t erinevused gruppide ning ajapunktide vahel ei olnud statistiliselt olulised $\left(F(5,233)=1,62, p>0,05, \eta^{2}=0,03\right)$. Seega osutavad tulemused, et õpilaste arusaam loovusest kui arendatavast omadusest ei süvenenud sekkumises osalemise toel. 


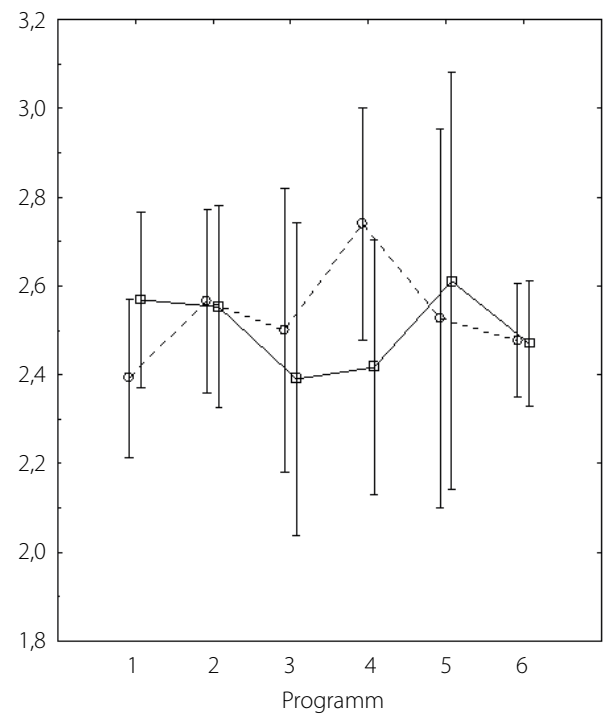

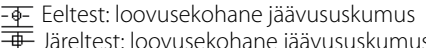

Joonis 2. Uskumused loovuse arendatavuse kohta sekkumis- ja kontrollgrupis eri ettevõtlusprogrammide rakendamise eel ja järel (suurem skoor näitab loovusega seotud suuremat jäävususkumust)

\section{Sotsiaalsed oskused eri programmide võrdluses}

Kui arenguuskumused võivad ettevõtlusprogrammides olla pigem vähe teadvustatud, siis sotsiaalseid oskuseid peetakse üsna üksmeelselt ettevõtlikkusning muude pädevuste kontekstis oluliseks. Siiski ei näita dispersioonalalüüs sotsiaalsete oskuste (enesekontrolli, empaatia, huumoritaju, prosotsiaalsuse) arengu kohta eri ettevõtlusprogrammide ning kontrollgrupiga tehtud võrdluses statistiliselt olulisi erinevusi ei enne ega pärast sekkumist $(F(5,169)=0,61$, $p>0,05)$.

\section{Üldvõimekuse ja ettevõtlusprogrammide koosmõju uuritud teguritele}

Haridusliku sekkumise mõju hindamisel tasub arvesse võtta, millised võimalikud individuaalsed erinevused või taustategurid võivad aidata selgitada või vahendada sekkumise mõju. Nii näiteks on võimalik, et keerukates uutes olukordades, mida ettevõtlusprogrammid pakuvad ning kus peab paindlikult palju uut infot töötlema, teadmisi praktikasse rakendama, otsuseid langetama ja neid vajaduse korral muutma, võivad edukamad olla kognitiivselt võimekamad, parema töömälu või eneseregulatsiooniga õpilased. Seepärast on tähtis välja selgitada tunnused, mille alusel saab valimi sees alarühmi eristada ning vaadata, kas ettevõtlusprogrammid avaldavad rühmadele erinevat mõju. Artikli 
aluseks olevas uuringus valiti selliseks taustateguriks üldvõimekuse näitajana kasutatav test (Raveni progressiivsed maatriksid, E-osa). Standardhälbe alusel jagati valim kolmeks grupiks (esimene grupp: $>-1 S D$, kolmas grupp: $<+1 S D$ ). Seejärel analüüsiti, kas sekkumis- ja kontrollgrupi alagruppides, mis on moodustatud võimekuse alusel, on võimete ja loovuse arendatavusega seotud uskumused ja sotsiaalsed oskused teinud läbi sarnased või erinevad muutused.
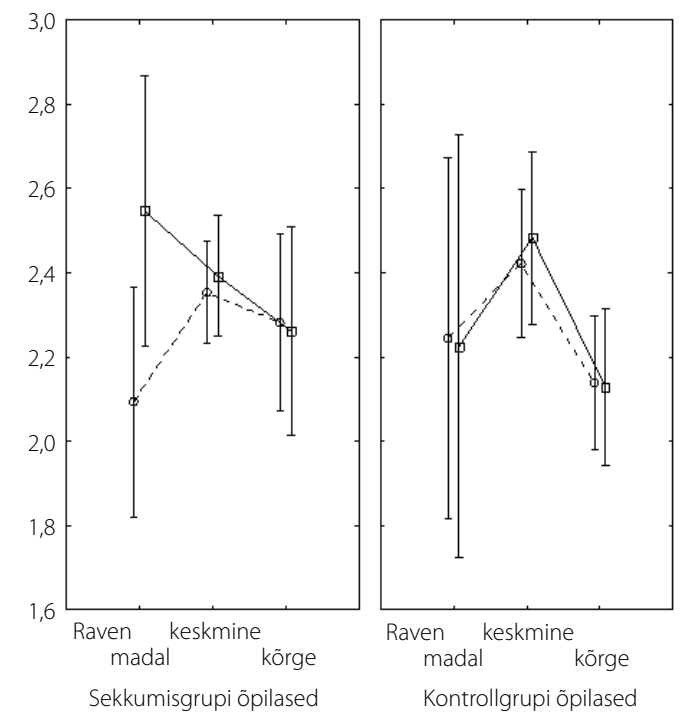

Eeltest: jäävususkumus

Joonis 3. Sekkumis- ja kontrollgrupi võimekusrühmade õpilaste uskumused võimekuse muudetavuse kohta esimesel ja teisel andmekogumisel (suurem skoor näitab suuremat jäävususkumust)

Jooniselt 3 ilmneb, et kahe teguri - ettevõtlusprogrammi ja üldvõimekuse koosmõju võimekusega seotud jäävususkumustele ei ole oluline $(F(2,226)=$ $1,54, p>0,05)$. Sama tulemus saadi ka loovusega seotud jäävususkumuste korral $(F(5,232)=1,1, p>0,05)$. Samuti kontrolliti, kas sotsiaalsed oskused arenevad ettevõtlusprogrammi läbinutel võimekusrühmades erinevalt või mitte. Ka selle näitaja puhul ei osutunud koosmõju mudel statistiliselt oluliseks $(F(2,168)=2,15, p>0,05)$.

Eeltoodut arvestades ei saa öelda ka seda, et ettevõtlusprogrammidest võidaksid iseäranis kindlad võimekusrühmad, näiteks tublimad või nõrgemad õpilased. Näib, et üldvõimekust silmas pidades ei mõjuta sekkumine õpilasi erinevalt. Samas ilmneb sekkumisgrupi kõige väiksema üldvõimekusega grupis tendents, et nendel õpilastel on pärast sekkumist nii võimekuse kui ka loovusega seoses tugevamad jäävususkumused ning kasinamad enesehinnangulised suhtlemisoskused, olgugi et statistiliselt mitteolulisel määral. 


\section{Arutelu}

Siinses uurimuses, mis on ettevõtlusprogrammide mõju-uuringu analüüsi esimene etapp, keskenduti mõnele potentsiaalselt ettevõtlikkusega seotud tegurile: võimekuse ja loovuse arendatavusega seotud uskumustele ning sotsiaalsetele oskustele. Ettevõtlusprogrammide eesmärk on ettevõtliku tegutsemise igakülgne arendamine. Ka siis, kui seda otsesõnu programmides ei rõhutata, võib oletada, et ettevõtlusprogrammid kujundavad vaikimisi õpilastes arusaama, et ettevõtlikkust saab arendada, ning edendavad ettevõtlike tegevuste raames asjakohaseid ja paindlikke sotsiaalseid oskusi. Uurimuses otsiti vastuseid küsimustele, kas ja kuidas muutuvad ettevõtlusprogrammides osalevate õpilaste uskumused ja sotsiaalsed oskused võrreldes kontrollgrupi omadega, kas eri ettevõtlusprogrammides osalemine seostub uuritud näitajate arenguga erinevalt ning kas edenemine uuritud näitajates on seotud vaimse võimekuse kui ühe individuaalse erinevuse dimensiooniga. Uurimistulemused ei näita, et programmides osalemine muudaks õpilaste arengut, mis avaldub vaatlusalustes muutujates, seda nii võrdluses kontrollgrupiga kui ka omavahel. Samuti ei ilmne, et need avaldaksid selektiivselt mõju võimekusrühmadele.

Üks võimalik põhjus, miks muutusi ei ilmnenud, võib tuleneda sellest, et vajadust toetada artiklis analüüsitud tegureid teadvustatakse vähe. Pole tõenäoline, et tegutsemise püsivusega seotud motivatsiooniaspektid (nt uskumused) ning sotsiaalsed oskused arenevad iseenesest, lihtsalt komplekssema programmitegevuse käigus. Võimalik, et kui kohaste võimekususkumuste toetamise vajadust ei teadvustata ja toetamise nimel sihipäraselt ei tegutseta, siis muutust ei toimu. Kuna mõlemas uuritud valdkonnas võivad õpetajate teadmised olla ebaühtlased, siis on võimalik, et siin uuritud varjatumaid ettevõtlikkuse alaoskusi ettevõtlusprogramm oluliselt ei toeta.

Uurimistulemused annavad ainest edasimõtlemiseks kahes suunas. Esiteks, eri sekkumisgruppides on õpilaste vastuste hajuvus mõnevõrra erinev, olgugi et statistiliselt mitteolulisel määral. Teadaolevalt on õpilase edenemine tõenäolisem siis, kui õpetamist kohandatakse tema hetkeomaduste järgi (Toomela, 2015). Edasi võiks küsida, kas programmides osalejate hulgas on õpilasi, kellele avaldas programm mingil põhjusel teistest erinevat mõju, ning kas see võiks osutada vajadusele mõelda õpilaste võimalikele erinevustele ja vajadusele pakkuda neile programmide rakendamisel eri tüüpi tuge. Teiseks, individualiseerimisvajadusele viitavad ka üldvõimekuse taseme ja ettevõtlusprogrammide koosmõju tendentsid. Taas ilmneb statistiliselt mitteolulise tulemusena, et üldvõimekuse poolest nõrgim grupp paistab ettevõtlusprogrammides osalemise järel enam silma jäävususkumustega (ehk kaldub arvama, et võimeid ei saa muuta) ning nõrgemate sotsiaalsete oskustega. Ilmselt oleks siinkohal huvitav 
jätkata indiviidikesksete analüüsidega, et uurida, milliste omadustega õpilaste tulemused osutuvad sekkumise järel viletsamaks ning kas andmete põhjal tekkinud muljel võib olla alust. Ka varasemate sekkumisuuringute (Blayney, Kalyuga, \& Sweller, 2010,2015) grupitasandi analüüsid on jätnud mulje edenemisest või vähemalt languse puudumisest, ent kui valim jagada nt võimekuse alusel alarühmadeks, võib ilmneda, et osale õpilastest mõjub uudne õpiolukord pigem sooritust pärssivalt.

Üks võimalik selgitus uskumustega seotud langustendentsile võib olla see, et kõige vähem võimekad õpilased on koolitegevustes sageli harjunud saama kehva tagasisidet. Õppekavavälises programmis osalemine paneb neile järjekordselt uudseid ootusi, eeldades tõenäoliselt head töömälu, mõtlemise paindlikkust, eneseregulatsiooni, koostööoskust, info kiiret integreerimist, leidlikkust - protsesse, mis võivad just selle grupi õpilastel teistest kauem aega võtta. On tõenäoline, et osa nõrgemaid õpilasi kogeb uute keeruliste õppeprogrammide kaudu järjekordselt ebaõnnestumist. See võib aga süvendada nende jäävususkumust, eriti siis, kui õpetajad-juhendajad ei toeta programmitegevuste vältel teadlikult juurdekasvu-uskumust, nt rõhutades, et uute asjade õppimine võtab kõigil aega ning et kui millegi õppimine nõuab pingutust ja tehakse vigu, ei ole see märk võimetusest, vaid on õppimise elementaarne osa. Õpetajad saaksid ehk veel enam tähele panna ja järele mõelda, millised õpilased vajavad teistsugust tuge võrreldes ülejäänud grupiga. Ka varasemad uuringud on näidanud, et koolid, kes püüavad luua tippsooritusele orienteeritud klassiruume, kus kõigile õpilastele on seatud suured ootused, ei tohi seejuures unustada, et erinevaid ópilasi on vaja eri viisil toetada, samuti tuleb märgata õppijate individuaalset pingutust ja arengut, mitte pelgalt sooritust ning anda informatiivset tagasisidet. Ilmselt kõik õpilased on võimelised oskustes-teadmistes edenema, aga seda ei saavutata kõiki samal viisil õpetades, vaid grupi sees paindlikult eri õpilasi erinevalt toetades (Boaler \& Foster, 2014; Cohen \& Lotan, 2014). Oluline on mitte teha järeldust, et õpilasi tuleks võimekuse põhjal suunata eraldi programmidesse, sest heterogeensed grupid kalduvad olema edukamad kui võimekuse järgi moodustatud grupid. Sellest vaatenurgast on kõigile kättesaadavad ettevõtlusprogrammid Eestis väga edumeelsed. Ent uurijad on rõhutanud, et grupisiseste erinevuste ignoreerimine võib sisuliselt tasalülitada programmi kättesaadavuse kasuteguri (Ricci, 2013).

Saadud tulemused ei näita sekkumise mõju, küll aga suunavad esitama edasisi küsimusi: millised võiksid olla uskumuste, sotsiaalsete oskuste, õpilase taseme ning eri sekkumisviiside korral edastatavate sõnumite vastastikseosed (sh nende muutumine ajas)? Teisisõnu, kuidas üks või teine hariduslik sekkumine suhestub õpilaste omadustega? Kuna uskumused kujunevad keskkonnalt saadava tagasiside põhjal ning samas kujundavad omakorda pingutamis- 
käitumist, siis võiksid edasised, sh indiviiditasandi analüüsid mõistete arengu, probleemilahendusoskuse, vältiva-pingutava õpikäitumise jm omaduste kohta aidata paremini mõista, millisena võiks õpilane, lähtudes oma hetkeomadustest, tegevusest ning selle kohta saadavast tagasisidest, oma keskkonda tajuda ning kuidas see suhestub tema motivatsiooniga.

\section{Piirangud}

Uuringu tulemuste tõlgendamisel tuleb tähele panna mitmeid aspekte, millest osa on universaalsed sekkumisuuringute probleemid, osa aga kontekstispetsiifilised.

Sekkumisuuringutes oleks korrektne, kui ka kontrollgrupi koolides toimuks mingit laadi (sekkumise oodatava mõju mõttes neutraalne) tegevus, et välistada olukord, kus sekkumine ehk kindlale grupile tähelepanu pööramine võiks mõjutada uuritud aspekte. Selline uuringu ülesehitus oleks olnud aga liiga töömahukas.

Vähemalt ühe programmi puhul oli programmis osalemine õpilaste jaoks vabatahtlik ning on võimalik, et valim oli selle programmi korral kallutatud ning tulemusi ei saa üldistada. Seega pole selge, millised oleksid tulemused, kui programmis osaleksid nii õpilased, kellel on programmi vastu esialgne huvi, kui ka need, kellel huvi ei ole. Sedalaadi küsimused on aga paratamatult seotud ettevõtlusprogrammide seniste piirangutega, mida tuleb üldpädevuste toetamisel arvesse võtta.

Küsimusele, kui pikk peaks olema sekkumine, et see oleks efektiivne, ei saa üheselt vastata, sest see sõltub paljudest asjaoludest. Pikemaajaline sekkumine on tõenäoliselt efektiivsem (Rosenzweig \& Wigfield, 2016). Siiski on võimekususkumuste kujundamise uuringud näidanud, et uskumusi on võimalik muuta ka lühiajalisema sekkumise kaudu (Blackwell et al., 2007; O'Rourke, Haimovitz, Ballwebber, Dweck, \& Popović, 2014; Walton, 2014).

Eraldi väärib tähelepanu fakt, et kontrollgrupi klassides oli üldvõimekuse algtase statistiliselt oluliselt kõrgem kui sekkumisgruppides. Kuna osa valimisse kuulunud koolidest kattus mõlemas grupis, s.t kontrollgrupp oli sekkumisklassi paralleelklass, võib tekkida küsimus, kas ettevõtlusprogramm on teadlikult sihitud kindlatele klassidele. Kui aga sekkumisgrupp oleks juba uuringu alguses olnud eduseisus, oleks see muutnud tulemuste tõlgendamise keerukamaks, tekitades küsimuse, kas võimalik edu programmis tuleneks õpilaste eelteadmistest ja -oskustest või programmist endast. Praegusel juhul polnud sekkumisgrupil võimekusega seotud eelist, ent hinnatud näitajates ei ilmnenud siiski muutust. Kuidas sellist tulemust tõlgendada, ei ole veel lõplikult selge. 
Johansen (2017) on Junior Achievementi õpilasfirmade programmi uuringus võtnud peale programmis osalemise kohustuse või vabatahtlikkuse arvesse ka õpilase rolli programmis ning programmis oldud aega. Siinses uurimuses ei analüüsitud üksikasjalikult, mida iga õpilane programmis täpselt tegi ning kui pikalt oli ta programmitegevustega hõivatud. Samuti ei hinnatud õpetajate tegevusi ja pädevusi programmide rakendamisel. Selline info aitaks aga kahtlemata programmide tähendust sisulisemalt tõlgendada.

\section{Kokkuvõtvad soovitused}

Edasised küsimused, millele on põhjust keskenduda, võiksid puudutada uuritud tunnuste väärtuste hajuvust osas uuritud gruppides, teisisõnu seda, kas ja mil määral erinevad õpilaste uskumused või sotsiaalsed oskused gruppide sees ning kas neid erinevusi saaks programmi rakendades arvesse võtta, näiteks keskendudes sõnaselgemalt nende õpilaste motivatsiooni toetamisele, kes kalduvad oma võimete arendatavuses kõhklema. Sama teemaga haakub ka analüüsitasand: kuivõrd tegu oli haridusuuringuga, oleks mõistlik teha ka indiviiditasandi statistilisi analüüse, et mõista, milliste omaduste või omaduste kombinatsioonidega õpilased võidavad programmidest enim ning millised vähim ning mis võivad olla selle põhjused.

Edasisidestavalt võib uuringust järeldada, et kui eesmärk on arendada ettevõtlusprogrammide kaudu õppijate ettevõtlikkust eri aspektides, siis oleks kasulik teadvustada vajadust toetada ka nende motivatsiooni ja sotsiaalseid oskusi ning omandada selleks sobivad viisid. Niisamuti on tähtis jälgida, et programmist saadav kogemus ei süvendaks õppijate arvamust iseenda võimekuse muutumatusest.

\section{Tänusõnad}

Uurimust on toetanud Euroopa Liit Euroopa sotsiaalfondi kaudu, mis finantseeris Haridus- ja Teadusministeeriumi eestvedamisel ellu viidud projekti „Ettevõtlusõppe programm Edu ja Tegu“.

\section{Kasutatud kirjandus}

Aus, K., \& Jõgi, A-L. (2014). Eesti põhikooliõpilaste spikerdamiskäitumise seosed võimekususkumustega erinevate motivatsiooniliste tegurite ja võimekuse ning teadmiste taustal. E. Kikas (toim.), Projekt „Üldpädevused ja nende hindamine“. Ülevaade projektist ja mõningaid 7.-9. klasside uurimuse tulemusi. Külastatud aadressil http://dspace.ut.ee/bitstream/handle/10062/49704/YPKoondAruanne.pdf. 
Baron, R. A., \& Markman, G. D. (2003). Beyond social capital: The role of entrepreneurs' social competence in their financial success. Journal of Business Venturing, 18(1), 41-60. https://doi.org/10.1016/S0883-9026(00)00069-0

Beauchamp, M. H., \& Anderson, V. (2010). SOCIAL: An integrative framework for the development of social skills. Psychological Bulletin, 136(1), 39-64. https://doi.org/10.1037/a0017768

Blackwell, L. S., Trzesniewski, K. H., \& Dweck, C. S. (2007). Implicit theories of intelligence predict achievement across an adolescent transition: A longitudinal study and an intervention. Child Development, 78(1), 246-263. https://doi.org/10.1111/j.1467-8624.2007.00995.x

Blayney, P., Kalyuga, S., \& Sweller, J. (2010). Interactions between the isolated-interactive elements effect and levels of learner expertise: Experimental evidence from an accountancy class. Instructional Science, 38(3), 277-287. https://doi.org/10.1007/s11251-009-9105-X

Blayney, P., Kalyuga, S., \& Sweller, J. (2015). Using cognitive load theory to tailor instruction to levels of accounting students' expertise. Educational Technology \& Society, 18(4), 199-210.

Boaler, J., \& Foster, D. (2014). Raising expectations and achievement: The impact of wide scale mathematics reform giving all students access to high quality mathematics. Retrieved from https://bhi61nm2cr3mkdgk1dtaov18-wpengine.netdna-ssl.com/ wp-content/uploads/2017/03/Raising-Expectations.pdf.

Cohen, E. G., \& Lotan, R. A. (2014). Designing groupwork: Strategies for the heterogeneous classroom (3rd ed.). New York: Teachers College Press.

Durlak, J. A., Weissberg, R. P., Dymnicki, A. B., Taylor, R. D., \& Schellinger, K. B. (2011). The impact of enhancing students' social and emotional learning: A metaanalysis of school-based universal interventions. Child Development, 82(1), 405432. https://doi.org/10.1111/j.1467-8624.2010.01564.x

Dweck, C. S., \& Leggett, E. L. (1988). A social-cognitive approach to motivation and personality. Psychological Review, 95(2), 256-273.

https://doi.org/10.1037/0033-295X.95.2.256

Elert, N., Andersson, F. W., \& Wennberg, K. (2015). The impact of entrepreneurship education in high school on long-term entrepreneurial performance. Journal of Economic Behavior \& Organization, 111, 209-223. https://doi.org/10.1016/j.jebo.2014.12.020

Hagel III, J., \& Brown, J. S. (2010, 23. nov). Do you have a growth mindset? Harvard Business Review. Retrieved from https://hbr.org/2010/11/do-you-have-a-growth-mindset.

Hogan, K., \& Dweck, C. (2016, 7. okt). How Microsoft uses a growth mindset to develop leaders. Harvard Business Review. Retrieved from https://hbr.org/2016/10/how-microsoft-uses-a-growth-mindset-to-develop-leaders.

Iarocci, G., Yager, J., \& Elfers, T. (2007). What gene-environment interactions can tell us about social competence in typical and atypical populations. Brain and Cognition, 65(1), 112-127. https://doi.org/10.1016/j.bandc.2007.01.008

Johansen, V. (2017). Innovation clusters for entrepreneurship education: A short summary of the main findings. Eastern Norway Research Institute. Retrieved from http://www.ja.ee/public/files/A\%20Short\%20Summary\%20of\%20the\%20Main\%20 ICEE\%20Findings_DEF.pdf. 
Johnston, I. (2017). Creating a growth mindset. Strategic HR Review, 16(4), 155-160. https://doi.org/10.1108/SHR-04-2017-0022

Kaldoja, M-L. (2014). Sotsiaalse pädevuse hindamine enesekohase küsimustikuga. E. Kikas (toim.), Projekt „Üldpädevused ja nende hindamine“. Ülevaade projektist ja mõningaid 7.-9. klasside uurimuse tulemusi (lk 50-61). Külastatud aadressil http://dspace.ut.ee/bitstream/handle/10062/49704/YPKoondAruanne.pdf.

Kaldoja, M-L. (2015). Sotsiaalne pädevus. E. Kikas \& A. Toomela (toim.), Oppimine ja õpetamine kolmandas kooliastmes. Üldpädevused ja nende arendamine (lk 185207). Tallinn: Eesti Ülikoolide Kirjastus.

Karwowski, M. (2014). Creative mindsets: Measurement, correlates, consequences. Psychology of Aesthetics, Creativity, and the Arts, 8(1), 62-70. https://doi.org/10.1037/a0034898

Keating, L. A., \& Heslin, P. A. (2015). The potential role of mindsets in unleashing employee engagement. Human Resource Management Review, 25(4), 329-341. https://doi.org/10.1016/j.hrmr.2015.01.008

Kikas, E. (2015). Sissejuhatus üldpädevuste käsitlusse. E. Kikas \& A. Toomela (toim.), Õppimine ja õpetamine kolmandas kooliastmes. Üldpädevused ja nende arendamine (lk 63-71). Tallinn: Eesti Ülikoolide Kirjastus.

Lans, T., Blok, V., \& Gulikers, J. (2015). Show me your network and I'll tell you who you are: Social competence and social capital of early-stage entrepreneurs. Entrepreneurship \& Regional Development, 27(7-8), 458-473. https://doi.org/10.1080/08985626.2015.1070537

Man, T. W., Lau, T., \& Snape, E. (2008). Entrepreneurial competencies and the performance of small and medium enterprises: An investigation through a framework of competitiveness. Journal of Small Business \& Entrepreneurship, 21(3), 257-276. https://doi.org/10.1080/08276331.2008.10593424

Molden, D. C., \& Dweck, C. S. (2006). Finding „meaning“ in psychology: A lay theories approach to self-regulation, social perception, and social development. American Psychologist, 61(3), 192-203. https://doi.org/10.1037/0003-066X.61.3.192

Mueller, C. M., \& Dweck, C. S. (1998). Praise for intelligence can undermine children's motivation and performance. Journal of Personality and Social Psychology, 75(1), 33-52. https://doi.org/10.1037/0022-3514.75.1.33

Murphy, M. C., \& Dweck, C. S. (2010). A culture of genius: How an organization's lay theory shapes people's cognition, affect, and behavior. Personality and Social Psychology Bulletin, 36(3), 283-296. https://doi.org/10.1177/0146167209347380

Mylonas, N., Kyrgidou, L., \& Petridou, E. (2017). Examining the impact of creativity on entrepreneurship intentions: The case of potential female entrepreneurs. World Review of Entrepreneurship, Management and Sustainable Development, 13(1), 84-105. https://doi.org/10.1504/WREMSD.2017.080749

O’Rourke, E., Haimovitz, K., Ballwebber, C., Dweck, C. S., \& Popović, Z. (2014). Brain points: A growth mindset incentive structure boosts persistence in an educational game. Proceedings of the SIGCHI conference on human factors in computing systems (pp. 3339-3348). Toronto. https://doi.org/10.1145/2556288.2557157

Põhikooli riiklik õppekava (2011). Riigi Teataja, RT I, 29.08.2014, 20. Külastatud aadressil https://www.riigiteataja.ee/akt/129082014020. 
Rattan, A., Savani, K., Naidu, N. V. R., \& Dweck, C. S. (2012). Can everyone become highly intelligent? Cultural differences in and societal consequences of beliefs about the universal potential for intelligence. Journal of Personality and Social Psychology, 103(5), 787-803. https://doi.org/10.1037/a0029263

Ricci, M. C. (2013). Mindsets in the classroom. Waco: Prufrock Press.

Romero, C., Master, A., Paunesku, D., Dweck, C. S., \& Gross, J. J. (2014). Academic and emotional functioning in middle school: The role of implicit theories. Emotion, 14(2), 227-234. https://doi.org/10.1037/a0035490

Rosenzweig, E. Q., \& Wigfield, A. (2016). STEM motivation interventions for adolescents: A promising start, but further to go. Educational Psychologist, 51(2), 146163. https://doi.org/10.1080/00461520.2016.1154792

Schommer, M. (1990). Effects of beliefs about the nature of knowledge on comprehension. Journal of Educational Psychology, 82(3), 498-504. https://doi.org/10.1037/0022-0663.82.3.498

Schommer-Aikins, M. (2004). Explaining the epistemological belief system: Introducing the embedded systemic model and coordinated research approach. Educational Psychologist, 39(1), 19-29. https://doi.org/10.1207/s15326985ep3901_3

Toomela, A. (2015). Arengust, õppimisest, õpetamisest ja pääsukestest. E. Kikas \& A. Toomela (toim.), Õppimine ja õpetamine kolmandas kooliastmes. Üldpädevused ja nende arendamine (15-31). Tallinn: Eesti Ülikoolide Kirjastus.

Venesaar, U., Täks, M., Arro, G., Malleus, E., Loogma, K., Mädamürk, K., ... Toding, M. (2018). Ettevõtluspädevuse mudel ettevõtlusõppe arendamise alusena. Eesti Haridusteaduste Ajakiri, 6(2), 118-155. https://doi.org/10.12697/eha.2018.6.2.06

Walton, G. M. (2014). The new science of wise psychological interventions. Current Directions in Psychological Science, 23(1), 73-82. https://doi.org/10.1177/0963721413512856

Õnapuu, K., \& Ots, A. (2015). Ettevõtlikkuspädevus. E. Kikas \& A. Toomela (toim.), Õppimine ja õpetamine kolmandas kooliastmes. Üldpädevused ja nende arendamine (lk 225-240). Tallinn: Eesti Ülikoolide Kirjastus.

Yeager, D. S., Walton, G. M., Brady, S. T., Akcinar, E. N., Paunesku, D., Keane, L., \& Dweck, C. S. (2016). Teaching a lay theory before college narrows achievement gaps at scale. Proceedings of the National Academy of Sciences, 113(24), E3341E3348. https://doi.org/10.1073/pnas.1524360113 


\section{Lisa}

Tabel. Küsimustike väidete faktorlaadungid eelandmekogumisel

\begin{tabular}{|l|c|c|}
\hline Küsimustiku väited & Jäävususkumus & Juurdekasvuuskumus \\
\hline Uskumus loovuse arendatavuse kohta 1 & 0,76 & $-0,22$ \\
\hline Uskumus loovuse arendatavuse kohta 2 & 0,68 & $-0,14$ \\
\hline Uskumus loovuse arendatavuse kohta 3 & 0,64 & $-0,12$ \\
\hline Uskumus loovuse arendatavuse kohta 4 & 0,52 & 0,27 \\
\hline Uskumus loovuse arendatavuse kohta 5 & $-0,15$ & 0,72 \\
\hline Uskumus loovuse arendatavuse kohta 6 & $-0,37$ & 0,69 \\
\hline Uskumus loovuse arendatavuse kohta 7 & $-0,07$ & 0,61 \\
\hline Uskumus loovuse arendatavuse kohta 8 & $-0,17$ & 0,55 \\
\hline
\end{tabular}




\title{
The effect of extracurricular entrepreneurship training programs on students' ability and creativity beliefs and social skills
}

\author{
Grete Arro $^{a 1}$, Elina Malleus ${ }^{\mathrm{b}}$, Juta Jaani', Anu Olvik ${ }^{\mathrm{d}}$ \\ a School of Educational Sciences, Tallinn University \\ ${ }^{b}$ School of Natural Sciences and Health, Tallinn University \\ 'School of Economics and Business Administration, University of Tartu \\ ${ }^{d}$ Estonian Entrepreneurship University of Applied Sciences
}

\section{Summary}

General competencies form a complex set of processes - cognitive and motivational processes, skills, knowledge, attitudes and values. General competences are becoming more and more a central issue in education, both at the level of scientific conceptualization, assessment and methods for supporting their development. One of general competencies - entrepreneurship competence - is being developed in Estonian schools through various extracurricular programs and initiatives. For example, there are international and local programs facilitating the foundation of student's companies; programs that integrate entrepreneurial learning into the school system; but also private enterprises offering entrepreneurial learning in a form of role play or other active learning methods that foster knowledge and skills essential for entrepreneurship. However, clear evidence is lacking about the effect of these entrepreneurship training programs on the students' entrepreneurial mindset and skills.

At the same time, in recent years there have been attempts to conceptualize the subcomponents and their relationships of entrepreneurial competence and in this process, a model of entrepreneurship competency has been created that relies on relevant pedagogical, entrepreneurial and psychological knowledge. According to the model, the entrepreneurship competence consists of four dimensions that divide, in turn, into sub-competencies (Venesaar et al., 2018). These are called self-management (regulating one's own motivation, ability beliefs, emotion regulation, and metacognition); value-oriented thinking and problem solving (higher-order cognitive processes like planning, problemsolving, but also a level of thinking development and value-based and ethical reasoning); solving social situations (social skills, cooperation, initiation) and

School of Educational Sciences, Tallinn University, Uus-Sadama 5, 10120 Tallinn, Estonia; grete.arro@tlu.ee 
more domain-specific knowledge about how to realize entrepreneurial ideas (knowledge about business environment, business possibilities and financial literacy). Thus it became possible to assess, whether the subcompetencies of the described model of entrepreneurship competency are facilitated and developed in entrepreneurship programs applied at the middle school level. Although the model has not yet been the basis for creating given educational programs for developing students' entrepreneurial skills and attitudes, it is still likely that successful interventions in this field catches the aspects that form the core for entrepreneurial activity, whether explicitly or implicitly.

Current analyses are a part of larger longitudinal study with the aim to assess and compare the effect of different entrepreneurship programs applied in middle school (8th grade) in various Estonian schools. The larger study concentrates on different motivational, cognitive and social aspects of entrepreneurship competency, but in the current analysis, only three components of entrepreneurial competency were examined, which are more related to the soft skills side of the entrepreneurship: beliefs about malleability of abilities; beliefs about malleability of creativity (both further referred to as "ability beliefs", based on Dweck \& Leggett, 1988; Schommer, 1990; Schommer-Aikins, 2004) and self-reported social skills (based on SOCIAL model, Beauchamp \& Anderson, 2010). Ability beliefs can be considered as the core motivational aspect related to effort- and challenge-related behaviours and resilience, assumingly fundamental in entrepreneurial activities. Social skills are also considered as mediating successful entrepreneurial activity. As a background variable, a general ability marker (Raven's progressive matrices, E-set) was evaluated. These variables were assessed with paper-and-pencil questionnaires and tests before and after students took part in entrepreneurship programs, both in program schools $(N=198)$ and matching control schools $(N=125$, mean age $14.11, S D=0.36)$. The test-retest interval of the longitudinal study was 7-8 months.

Results indicated no significant difference in ability beliefs related to general ability and creativity, and self-reported social skills between schools where students took part in different entrepreneurship programs compared to control schools. Specifically, there were no differences in given variables between preand post-intervention data collection in the program school sample and the control group. Also, there were no differences in studied variables between children participating in different entrepreneurship programs, both pre- and post-intervention. Also when tested for cognitive abilities, no interaction effect of cognitive ability or taking part in the program was revealed. Thus it seems that entrepreneurship programs do not explicitly affect beliefs about the malleability of abilities and creativity, as well as self-reported social skills compared to controlled schools. 
Various explanations can be suggested as to the result revealing no significant change in assessed variables in students participating in entrepreneurship programs. First, although entrepreneurship education programs aim, explicitly or implicitly, at enhancing resilience and perseverance, it is assumed that without the teachers' specific knowledge of how ability beliefs relate to the task-oriented behaviour and how to support adaptive beliefs, the change is unlikely to occur. Second, when offering a program at group level, it may be that various children perceive or interpret the intervention in different ways and thus need a slightly different kind of intervention. Not all students may get such an experience from the program that supports their underlying subcompetencies of entrepreneurship. Indeed, although insignificantly, subgroup analysis revealed that in the intervention group, the children with the weakest level of general ability reported insignificantly more fixed mindset and poorer social skills after the intervention. A similar pattern was not apparent in the control group. Although the numbers of subgroups were modest and the result non-significant, one may further hypothesize that the slower-learning students may perceive the new, challenging extracurricular learning context as yet another evaluation of their abilities, thus lowering their belief that they might do well in a given field. Hence, in future studies, individual-level analyses would be necessary to understand better the profiles and needs of individual learners in the extracurricular programs.

Keywords: entrepreneurship training in middle school, development of entrepreneurship competence, ability beliefs, self-reported social skills 